\title{
Effects of Bovine Somatotropin on $\beta$-Casein mRNA Levels in Mammary Tissue of Lactating Cows
}

\author{
J. Yang, ${ }^{1}$ B. Zhao, ${ }^{1}$ V. E. Baracos,${ }^{2}$ and J. J. Kennelly ${ }^{3}$ \\ ${ }^{1}$ Department of Human Nutrition, Food and Animal Sciences, University of Hawaii, Honolulu 96822 \\ ${ }^{2}$ Department of Oncology, and \\ ${ }^{3}$ Department of Agricultural, Food and Nutritional Sciences, University of Alberta, Edmonton, \\ Alberta, Canada T6G 2P5
}

\begin{abstract}
Bovine somatotropin (bST) increases milk production in lactating cows through its effect on nutrient partition and maintenance of mammary cell function. A positive relationship between bST treatment and abundance of $\beta$-casein mRNA in mammary tissues from lactating cows was hypothesized. In mammary tissue isolated from 14 midlactation Holstein cows, $\beta$-casein mRNA was $35.4 \%$ higher among 7 cows receiving continuous bST infusions at $29 \mathrm{mg} / \mathrm{d}$ for $63 \mathrm{~d}$ compared with tissue from 7 untreated control cows. To investigate whether increased $\beta$-casein mRNA resulted from a direct effect of bST on the mammary gland, explants of mammary tissue from other lactating cows that had not received bST were incubated with bST and prolactin in 2 experiments. Mammary explant cultures taken from 2 lactating cows that had not been milked for $48 \mathrm{~h}$ were supplemented with either prolactin or bST. Both prolactin and bST stimulated higher levels of $\beta$-casein mRNA in the mammary explants compared with their nonsupplemented counterparts. Explant cultures from 4 additional lactating cows were prepared from rear quarter mammary tissue subjected to milking intervals of $6 \mathrm{~h}$ for right rear quarters or $20 \mathrm{~h}$ for left rear quarters. Both bST- and prolactin-mediated increases in $\beta$-casein mRNA were dependent on milking intervals. That is, levels of $\beta$-casein mRNA were increased by bST or prolactin supplementation in explants isolated from the mammary quarters biopsied $20 \mathrm{~h}$ after milking but not for those biopsied at $6 \mathrm{~h}$ after milking. Results are consistent with a potential role for bST in up-regulating or sparing $\beta$-casein mRNA levels in lactating bovine mammary tissue in a manner similar to prolactin.
\end{abstract}

(Key words: bovine, growth hormone, lactation, mammary gland)

Abbreviation key: $\mathbf{B M}=$ basal medium, $\mathbf{G H}=$ growth hormone.

Received September 8, 2004.

Accepted April 12, 2005.

Corresponding author: J. Yang; e-mail: jinzeng@hawaii.edu.

\section{INTRODUCTION}

Bovine growth hormone (GH), also known as somatotropin (bST), is a potent galactopoietic hormone that enhances lactation in dairy cattle. It is produced in the anterior pituitary gland and secreted into the blood circulation. Earlier research documented that the maintenance of lactation by hormonal regulation differs in ruminants and rodents. Prolactin is less important for maintaining lactation in ruminants even though it is a major hormone for rodent lactation. Other studies showed that once lactation had been restored in hypophysectomized goats, injection of GH, triiodothyronine, and dexamethasone could maintain milk secretion for several weeks (Cowie et al., 1964). Administration of exogenous bST consistently stimulated milk production in established lactating dairy cattle (Dahl et al., 1993). The effects of bST in lactating cows include increased nutrient supply to the mammary gland, lactation persistency, and enhanced capacity for cell proliferation (Bauman, 1999; Capuco et al., 2001).

It is believed that the effect of somatotropin on the mammary gland is indirectly mediated by the influence of IGF-I on milk synthesis (Bauman and Vernon, 1993). Other evidence suggests that somatotropin directly regulates milk synthesis by affecting the mammary gland. Bovine GH induces mammary parenchymal proliferation and epithelial cell growth in lactating cows (Knight et al., 1990). Growth hormone receptor mRNA and protein were detected in bovine mammary gland tissue (Glimm et al., 1990; Plath-Gabler et al., 2001; Sinowatz et al., 2000). Prolactin induces lactation through its direct effects on the mammary gland. It is known that prolactin binds to its receptor on the surface of mammary cells, then activates Janus kinase 2 (Jak2) and signal transducer and activator of transcription 5 (Stat5) in the cytoplasm (Campbell et al., 1994; Wakao, et al., 1994; Grimm et al., 2002). It was shown that the GH receptor was associated with Jak2 in transfected $\mathrm{Nb}-2$ cells (Argetsinger et al., 1993). We previously demonstrated that bovine $\mathrm{GH}$ and prolactin induced Stat5 DNA binding activity in mammary explants from lactating cows (Yang et al., 2000a). However, in vitro or in 
vivo data are lacking that would demonstrate whether bovine GH directly affects the mammary gland-either through the stimulation of mammary cell proliferation or through other basic mammary cell functions, such as milk protein and fatty acid synthesis (Accorsi et al., 2002).

In the current study, the effects of bST infusion on $\beta$ casein mRNA levels in the mammary gland of lactating cows were examined. Effects of direct application of either bST or prolactin to mammary explant culture on $\beta$-casein mRNA abundance were also compared to determine whether a positive relationship existed between bST treatment and abundance of $\beta$-casein mRNA in the mammary tissue from lactating cows.

\section{MATERIALS AND METHODS}

\section{Animals}

Studies were carried out in compliance with the guidelines of local institutional committees of vertebrate animal care and use. Mammary tissue samples from 14 Holstein cows (7 control and 7 bST-treated cows) in midlactation provided by H. A. Tucker (Michigan State University, East Lansing, MI) were used to study effects of hormonal infusion on $\beta$-casein mRNA abundance. These multiparous cows were at midlactation (d 118 to 181), and they were not pregnant. They were randomly assigned to receive continuous bST infusion $(29 \mathrm{mg} / \mathrm{d}$; Somavubove, Pharmacia \& Upjohn Co, Peapack, NJ) or no infusion (controls) for $63 \mathrm{~d}$. As earlier reported, administration of bST to those lactating cows for $63 \mathrm{~d}$ resulted in a significant increase in milk protein yield over the nontreated, control cows $(P<$ 0.01; Binelli et al., 1995), and serum GH concentrations were elevated approximately 6 -fold by bST treatment (Dahl et al., 1993). Infused animals and controls were sacrificed at the end of treatments, approximately $8 \mathrm{~h}$ after the afternoon milking, and mammary tissue was removed within $20 \mathrm{~min}$ after sacrifice (Binelli et al., 1995). Tissue was frozen and stored at $-70^{\circ} \mathrm{C}$ until RNA isolation.

Six Holstein cows from the dairy farm of the University of Alberta were used in mammary explant studies. Animals in midlactation (d 148 to 165) were used for obtaining mammary tissue. These cows did not receive bST or other hormone treatment. They were fed a total mixed ration containing $50 \%$ concentrate and $50 \%$ forage and were housed in tie-stalls in the research farm.

\section{Mammary Explant Culture}

Bovine mammary tissue was obtained by biopsy (Knight et al., 1992b). Deep sedation of the cow was achieved by slow intravenous injection of xylazine. Lo- cal anaesthesia was achieved by a line block with subcutaneous injection of 5 to $10 \mathrm{~mL} 2 \%$ lignocaine hydrocholoride. A 5- to 10-g portion of secretory tissue was surgically removed. Explants were immediately prepared and cultured as described subsequently. The initial mammary tissues for making explants were obtained from 2 cows that had not been milked for $2 \mathrm{~d}$ to reduce effects of milking on hormone secretion. Then, further tissue culture experiments were carried out with mammary tissue obtained from 4 cows at different milking intervals for mammary quarters. The right and left quarters of the mammary gland were separately milked. The right quarters of mammary gland were milked twice daily at 0400 and $1600 \mathrm{~h}$, and the left quarters were milked once daily at $1600 \mathrm{~h}$ for $2 \mathrm{~d}$ before mammary gland biopsy. Mammary tissues from right rear and left rear quarters were separately biopsied at 1000 and $1200 \mathrm{~h}$, respectively, such that mammary tissues from right rear quarters were biopsied at about $6 \mathrm{~h}$ after milking and tissues from left rear quarters were biopsied at about $20 \mathrm{~h}$ after the previous milking, respectively.

Mammary explant culture was carried out following the described method by Topper et al. (1975) with modifications by Yang et al. (2000a). Briefly, mammary tissue pieces (maximum thickness in any dimension, 1 $\mathrm{mm}$ ) were prepared in Medium 199 with Earle's salts (Invitrogen, Carlsbad, CA) immediately after obtaining the tissue by biopsy. For each treatment and milking interval, 50 to $100 \mathrm{mg}$ of tissue (50 to 100 pieces of 1$\mathrm{mm}^{3}$ tissue) were used. The basal medium consisted of Medium 199 supplemented with $1 \mathrm{mg} / \mathrm{mL}$ BSA, $1 \mu \mathrm{g} /$ $\mathrm{mL}$ hydrocortisone, and $1 \mu \mathrm{g} / \mathrm{mL}$ insulin (Sigma, St. Louis, MO). The bovine GH (95\% purity by SDS polyacrylamide gel electrophoresis) was a gift from A. F. Parlow through the National Hormones and Pituitary Program, National Institute of Diabetes and Digestive and Kidney Disease (Bethesda, MD). The physiologic range of serum prolactin and bST concentration in lactating cows were approximately 10 to $140 \mathrm{ng} / \mathrm{mL}$ and 3 to $6 \mathrm{ng} / \mathrm{mL}$, respectively. Serum ST ranged from 10 to $20 \mathrm{ng} / \mathrm{mL}$ in cattle treated with bST (Dahl et al., 1993). Previously, we demonstrated that prolactin and bovine $\mathrm{GH}$ at concentrations of $50 \mathrm{ng} / \mathrm{mL}$ were appropriate for bovine mammary explant culture (Yang et al., 2000a). Final concentrations of $50 \mathrm{ng} / \mathrm{mL}$ for prolactin and bovine GH were used in the explant culture. Explants were cultured in 14-mL sterile Falcon tubes at $37^{\circ} \mathrm{C}$ and bubbled with $5 \% \mathrm{CO}_{2}$ and $95 \% \mathrm{O}_{2}$ for $2 \mathrm{~h}$. Freshly isolated tissues as well as cultured explants were frozen in liquid nitrogen and stored at $-70^{\circ} \mathrm{C}$ until RNA isolation. 


\section{Detection of $\beta$-Casein mRNA by Northern Blotting}

Total RNA was isolated from mammary tissue using TRIzol Reagent (Invitrogen). Frozen mammary tissue $(0.2$ to $1 \mathrm{~g})$ at $-70^{\circ} \mathrm{C}$ was ground in liquid nitrogen with a mortar and pestle, then homogenized in TRIzol reagent using a Polytron power homogenizer at maximum speed for $30 \mathrm{~s}$. Based on the manufacturer's instructions, total RNA was separated and precipitated from protein components of the tissue. From each sample, $20 \mu \mathrm{g}$ of RNA were denatured with $50 \%$ formamide/ $7 \%$ formaldehyde (vol/vol) and subjected to electrophoresis in a 1.2\% agarose/formaldehyde gel. The RNA was transferred to Nitropure membranes (GE Osmonics Labstore, Minnetonka, MN) by overnight capillary transfer. The density of the $18 \mathrm{~S}$ ribosomal RNA band in the Nitropure membrane was quantified by Kodak Gel Logic 200 Imaging System (Kodak, Rochester, NY). The DNA probe for Northern blotting was a bovine $\beta$ casein cDNA, a gift from A. Persuy and was generated by a random primer labeling kit (Invitrogen) and $[\alpha-$ ${ }^{32}$ P]dATP (Amersham, Piscataway, NJ). The radioactive probe was passed through a Sephadex G-50 spin column. The membrane was prehybridized in $5 \times$ Denhardt's solution with $6 \times$ SSPE and $0.5 \%$ SDS for $1 \mathrm{~h}$ at $65^{\circ} \mathrm{C}$ then hybridized with the DNA probe for 16 to 18 $\mathrm{h}$ at $65^{\circ} \mathrm{C}$. After washing, the membrane was subjected to autoradiography with X-omat AR x-ray film (Kodak). For any given mammary samples within each experiment, the RNA for all treatment groups, i.e., control vs. stimulated, were simultaneously processed (prehybridized, hybridized, washed, and exposed to x-ray film) under the same conditions. Therefore, comparisons between treatments are valid within each experiment.

\section{Quantification of $\beta$-Casein mRNA and Statistical Analyses}

The $18 \mathrm{~S}$ ribosomal RNA is directly proportional to the amount of total RNA for a given sample. The density of $\beta$-casein mRNA from Northern blotting was analyzed by Imaging Densitometry (BioRad Laboratories, Mississauga, $\mathrm{ON}$ ), and the density units of adjusted volume $(\mathrm{OD} \times \mathrm{mm} \times \mathrm{mm})$ was obtained for each $\beta$-casein mRNA band. The density of ethidium bromide-stained $18 \mathrm{~S}$ rRNA band of each sample was used to correct sample loading and transfer variation. Therefore, the $\beta$-casein mRNA abundance of each sample was expressed as adjusted volume based on the density of its $18 \mathrm{~S}$ rRNA band. The least squares means and standard errors of the means were obtained from the GLM procedure of SAS (1990). The significance of $\beta$-casein mRNA difference between bST-treated and controls was assessed using ANOVA for paired data. In analyzing the effects of bST treatment on $\beta$-casein mRNA in explants, data

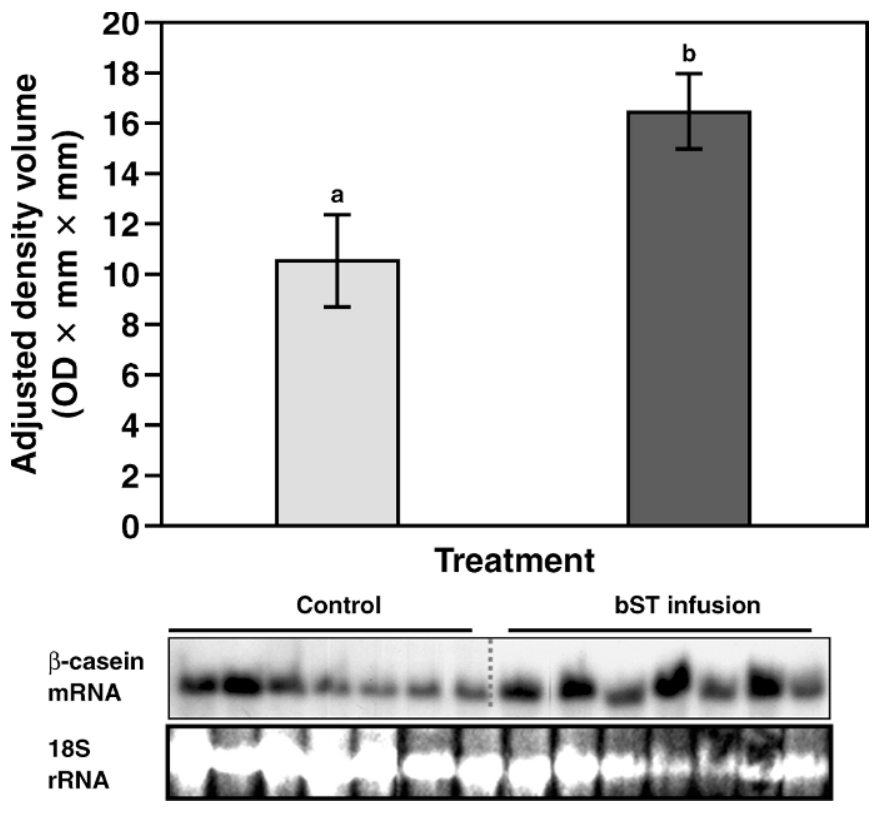

Figure 1. Effects of bST infusion on $\beta$-casein mRNA abundance in lactating cows. Mammary tissues were obtained from 14 cows: 7 cows were used as controls, 7 cows received bST infusion for $63 \mathrm{~d}$. Total RNA was isolated from the mammary tissue, and $20 \mu \mathrm{g}$ of total RNA were used for detection of $\beta$-casein mRNA. The density of the $\beta$-casein mRNA hybridization band in X-ray film was scanned and quantified. The least squares means and standard errors of the adjusted densities from each treatment $(n=7)$ are shown. Bars identified by a different letter differ at $P<0.05$. OD $=$ Optical density.

were subjected to split-block analysis of variance with repeated measurements. The statistical model included cow, repeat, and treatment (bST, prolactin, untreated), and 2 -way interactions. The dependent variable was $\beta$ casein mRNA level. The main effects of cow and treatment were tested using the cow $\times$ treatment interaction mean square as the error term. No significant interaction between treatment and repeat was present in both explant experiments $(P>0.05)$. Differences within each set of least squares means were compared by Student $t$-test and presented in the figures. Significance was determined at $P<0.05$.

\section{RESULTS}

\section{Effects of bST on $\beta$-Casein mRNA Abundance in Lactating Cows}

The effect of continuous bST infusion on mammary $\beta$-casein mRNA abundance was investigated in control and bST-treated Holstein cows in midlactation (Figure 1). The mammary tissues from bST-treated cows had significantly higher $(35.4 \% ; P<0.05) \beta$-casein mRNA levels compared with control cows. 


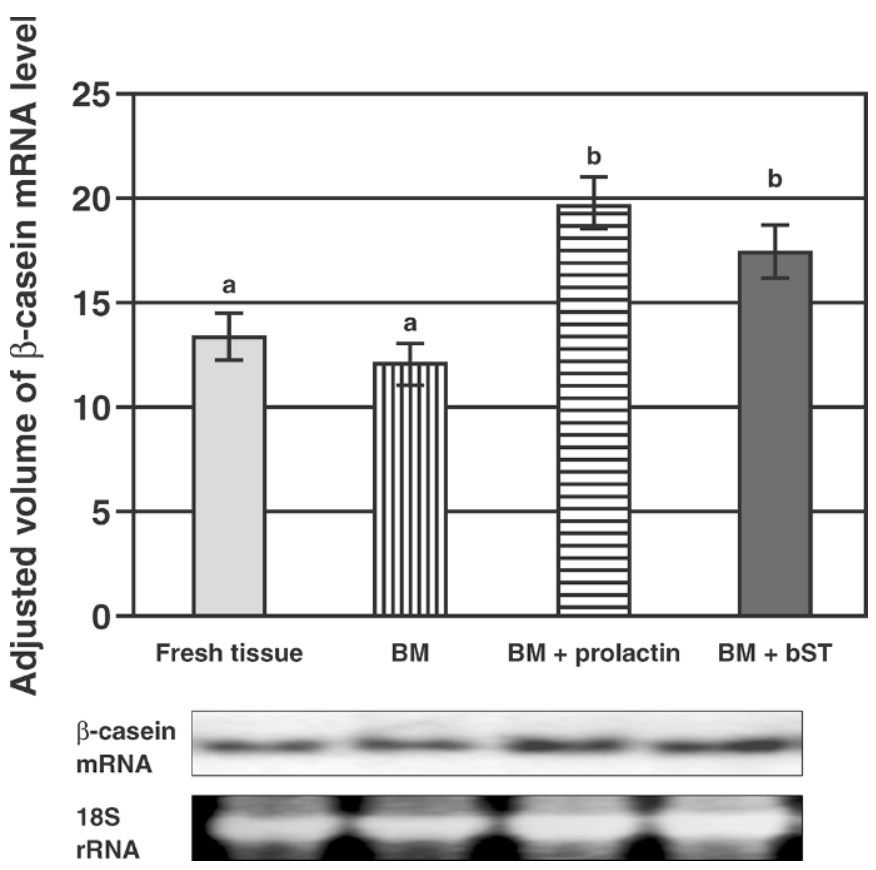

Figure 2. The effects of prolactin and bST supplementation on $\beta$ casein mRNA abundance in bovine mammary explant culture. Mammary tissue was collected at $48 \mathrm{~h}$ after previous milking, and either immediately frozen (fresh tissue) or made into explants and cultured in basal medium (BM) or in BM supplemented with either prolactin or bST for $2 \mathrm{~h}$. The abundance of $\beta$-casein mRNA in the tissue and explants was obtained by scanning the X-ray autoradiogram of Northern blotting. The means \pm SEM from 2 experiments (2 cows) with 4 to 5 repeats for each treatment are presented in the graph. One representative X-ray autoradiogram and its corresponding ethidium bromide-stained 18S rRNA gel image were shown. Treatments with different letters differ at $P<0.05$.

\section{Effects of bST Treatment on $\beta$-Casein mRNA in Bovine Mammary Explants}

To test the effects of bST on $\beta$-casein mRNA levels in bovine mammary explants, mammary tissue was obtained from cows in midlactation by biopsy. Before mammary biopsy, cows had not been milked for $48 \mathrm{~h}$ to reduce any confounding effects of milking-induced hormones on milk protein gene expression. Levels of $\beta$ casein mRNA in the fresh tissue (un-incubated) and in the cultured explants were detected by Northern blot analysis, and the results are shown in Figure 2. The level of $\beta$-casein mRNA in the cultured explants was significantly increased by either prolactin or bST supplementation $(P<0.01)$. Prolactin and bST treatment increased $\beta$-casein mRNA levels by $64 \%$ and $44 \%$, respectively, over the tissue cultured in basal medium. There was no difference between $\beta$-casein mRNA levels in the explants cultured in basal medium (hydrocortisone and insulin) and in fresh tissue $(P>0.05)$.

To investigate whether different milking intervals may affect hormone-induced $\beta$-casein mRNA changes, explant cultures from 4 cows were prepared from rear quarter mammary tissue subjected to milking intervals of $6 \mathrm{~h}$ for right rear quarters or $20 \mathrm{~h}$ for left rear quarters. The initial steady-state level of $\beta$-casein mRNA from the left quarter mammary tissue (biopsied $20 \mathrm{~h}$ after milking) was reduced by approximately $20 \%$ compared with the right quarter tissue (biopsied $6 \mathrm{~h}$ after milking; $P<0.05$ ). Addition of either prolactin or bST did not significantly alter $\beta$-casein mRNA levels in explants made from the right quarter mammary tissue (Figure 3). In contrast, in explants made from the left quarter of mammary tissue (biopsied at $20 \mathrm{~h}$ after milking), prolactin and bST increased $\beta$-casein mRNA levels by 154 and $80 \%$, respectively (Figure 3 ).

\section{DISCUSSION}

The effects of continuous bST administration on milk production in cattle were noteworthy; however, the effects of bST on mRNA expression in the mammary gland of lactating daily infusion of bST for $63 \mathrm{~d}$ significantly increased $\beta$-casein mRNA levels. To investigate whether the increased $\beta$-casein mRNA resulted from a direct effect of bST on the mammary gland, we cultured mammary explants in the presence of either bST or prolactin. The data collected from these experiments demonstrate that bST functions in a way similar to prolactin by up-regulating $\beta$-casein mRNA levels.

Our results reveal that prolactin had a significant effect on $\beta$-casein mRNA levels in mammary explants made from lactating cows compared with cultures treated with only hydrocortisone and insulin. Prolactin, hydrocortisone, and insulin are necessary for maximal accumulation of $\beta$-casein mRNA in rodents and ruminants (Chomczynski et al., 1984; Choi et al., 1988; Topper and Freeman, 1980; McFadden et al., 1989), and hydrocortisone alone cannot induce $\beta$-casein mRNA in mammary organ cultures or in vivo (Devinoy et al., 1978; Matusik and Rosen, 1980). Administration of prolactin for $2 \mathrm{wk}$ does not alter milk yields or milk components (fat, lactose, and protein), but does increase the concentration of $\alpha$-lactalbumin in lactating cows (Plaut et al., 1987). Choi et al. (1988) reported that prolactin alone induced several milk protein mRNAs in bovine mammary explants. In addition, prolactin, bST, and IGF, were capable of suppressing cellular apoptosis in bovine mammary explants, suggesting a role for these hormones in preventing mammary involution (Accorsi et al., 2002). It is unclear what effect prolactin may have on $\beta$-casein mRNA degradation and steady-state levels in bovine mammary tissue. Prolactin, in association with insulin and hydrocortisone, regulates the rate, transcription, and stability of $\beta$-casein mRNA in rat mammary explants. Addition of prolactin increases the 
C

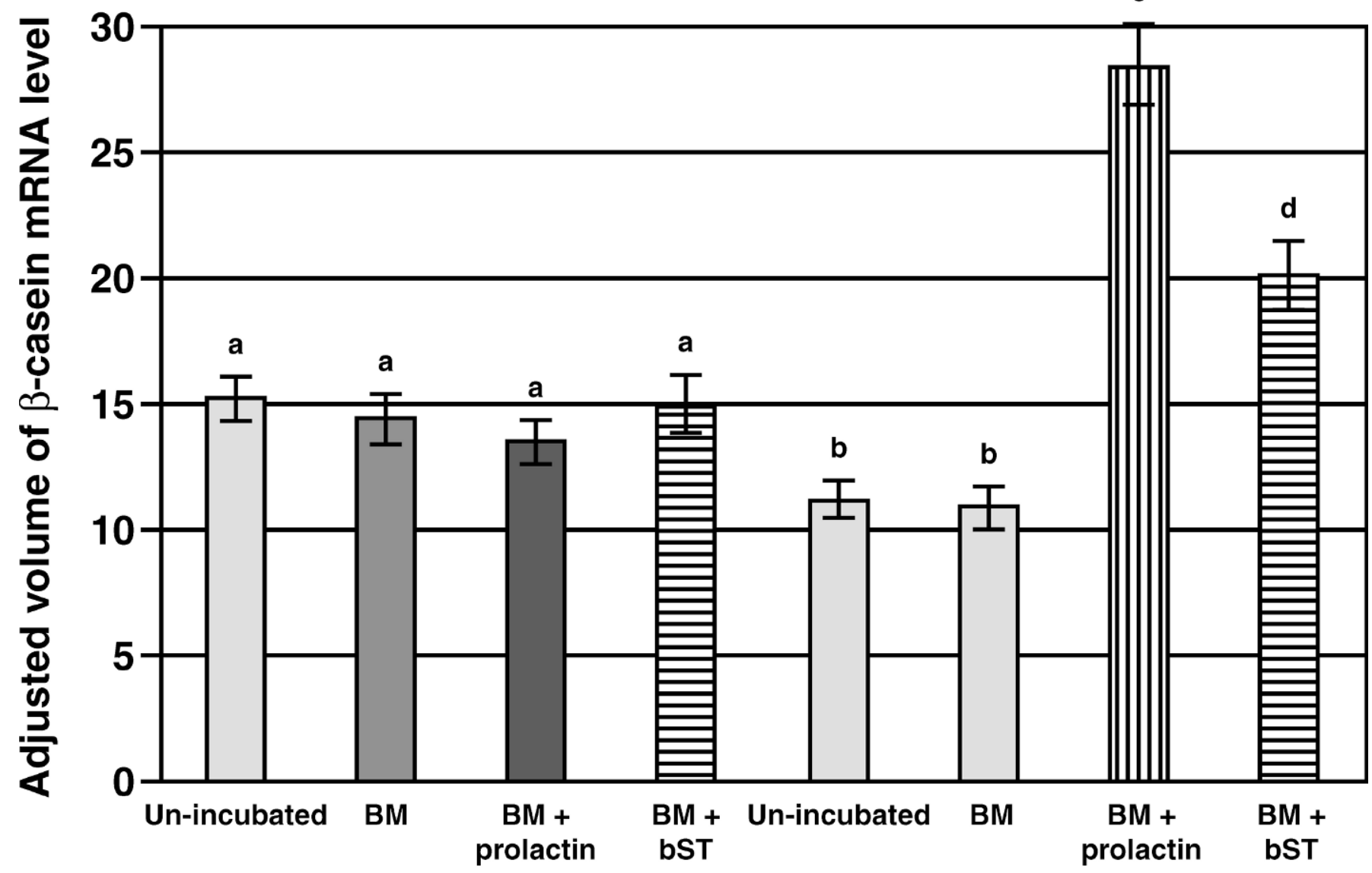

Mammary gland: Right quarter (6h from milking) Left quarter (20h from milking)

Hormone: Un-incubated BM Prolactin bST Un-incubated BM Prolactin bST

$\beta$-casein mRNA

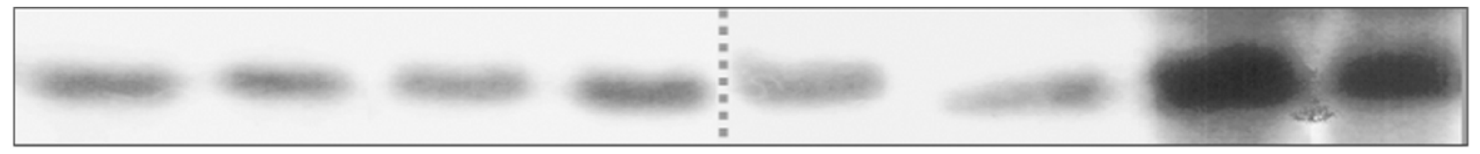

$18 S$ rRNA

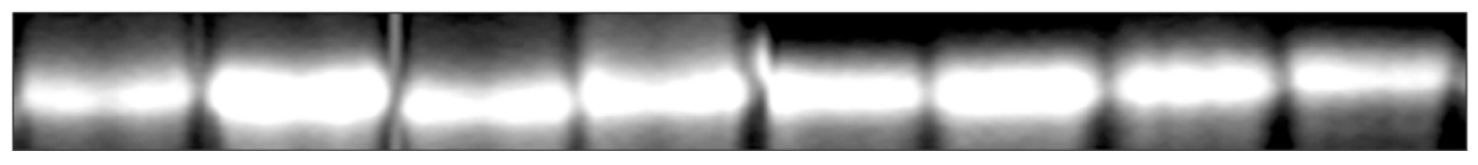

Figure 3. Effects of prolactin and bST on $\beta$-casein mRNA in explants made from mammary tissue receiving different daily milking time treatment. The right and left mammary quarters of 4 midlactation cows had been separately milked at twice and once daily for $2 \mathrm{~d}$, respectively. The right and left mammary tissues were separately surgically biopsied at about 6 and $20 \mathrm{~h}$ after the previous milking, respectively, and then made into explants and cultured with different hormone treatments. As shown in the graph, basal medium (BM) represents BM containing insulin and hydrocortisone, BM + prolactin represents the BM supplemented with prolactin, and BM + bST represents the BM supplemented with bST. The amount of $\beta$-casein mRNA was obtained by scanning the X-ray autoradiogram of Northern blotting. The means \pm SEM from 4 cows with 4 to 5 repeats for each treatment are presented in the graph. One representative X-ray autoradiogram and its corresponding ethidium bromide-stained 18S rRNA gel image were shown. Treatments with different letters differ at $P<0.05$.

rate of transcription of $\beta$-casein mRNA approximately 2 -fold and the mRNA half-life 17-fold (Rosen et al., 1980). Several research reports have shown that prolac- tin increases Stat5 activity in bovine mammary cells (Yang et al., 2000a; Wheeler et al., 2001; German and Barash, 2002). We believe that the increases in $\beta$-casein 
mRNA levels in response to prolactin observed here most likely reflect the synergistic actions of insulin and glucocorticoid on the regulation of RNA transcription and degradation.

The results from in vitro experiments demonstrated that bST had an effect similar to prolactin in up-regulating $\beta$-casein mRNA levels. Several studies have reported the effects of bST on casein protein levels and mammary function. Mammary explants from lactating cows treated with bST exhibited no change in casein synthesis, fat synthesis, or $\alpha$-lactalbumin secretion (Gertler et al., 1983). Also, in lactating heifers, bST treatment had no effect on $\beta$-casein protein synthesis (McFadden et al., 1989). Accorsi et al. (2002) reported that bST, similar to prolactin, attenuated bovine mammary cellular apoptosis. Those researchers hypothesized that bST's anti-apoptotic action was due to its ability to stimulate IGF-I synthesis and suppress IGFI binding protein-5 (Wilde et al., 1997). We did not analyze IGF-I levels in our explant culture. The explant incubation time is relatively short in this study; therefore, a direct effect of bST on mammary cells cannot be excluded based on the rapidity with which $\beta$-casein mRNA up-regulation occurred. We hypothesize that bST mediates increases in $\beta$-casein mRNA levels through regulation of mRNA degradation, as there is more evidence supporting a role for bST in preventing mammary involution. However, additional evidence is needed to clarify whether bST directly affects bovine mammary epithelial cells.

The results from experiments examining hormoneinduced changes in $\beta$-casein mRNA levels in mammary tissue subjected to different milking time treatments are consistent with a role for bST in retardation of mammary involution. Studies have shown that milking intervals affect ruminant mammary cell function. A change in milking frequency-from twice to once daily-temporarily disrupted tight junction integrity in cows and goats (Stelwagen et al., 1994). Initiation of mammary tight junction disruption was observed $21 \mathrm{~h}$ after milking in goats (Politis et al., 1989). Stelwagen et al. (1994) demonstrated that administration of bST significantly recovered the milk yield loss from once daily milking. In the current study, addition of prolactin or bST to the explant cultures made from right quarter mammary gland tissues and biopsied $6 \mathrm{~h}$ after milking did not lead to increases in $\beta$-casein mRNA. However, explant cultures made from the left quarter of the mammary gland and biopsied $20 \mathrm{~h}$ after milking responded positively to both hormones. In ruminants, individual mammary glands are under local control and function unilaterally (Knight et al., 1992a; Li et al., 1999). In the current study, the supply of lactational hormones to the left and right quarters of the mammary gland were assumed to be the same, although they were subjected to different milking intervals. It is likely that $\beta$ casein mRNA levels are under the influence of local environmental changes within mammary gland quarters. This is true of Stat5 activity, as we have previously observed local changes in Stat5 activity in response to different milking frequency treatments (Yang et al., $2000 \mathrm{~b})$. The tissue from the left mammary quarter had a longer recovery period following milking $(20 \mathrm{~h})$, which resulted in a relatively lower ( $20 \%$ less) level of $\beta$-casein mRNA than in the right mammary quarter, which had a smaller recovery period $(6 \mathrm{~h})$. In the follow-up explant culture, increases in $\beta$-casein mRNA levels were not seen in response to hormone supplementations in the mammary tissue biopsied $6 \mathrm{~h}$ after milking, which may indicate that $\beta$-casein mRNA levels were saturated at the time of biopsy. In contrast, the left quarter of mammary tissue, having a relatively lower level of $\beta$-casein mRNA at the time of biopsy, responded to prolactin and bST supplementation. Moreover, $\beta$-casein mRNA levels exceeded the initial levels present in the right quarter tissue. We believe that these high levels of $\beta$-casein mRNA observed after prolactin and bST treatment reflect a transient response to these hormones. Data in the current study are also consistent with the idea that changes in the amount of $\beta$-casein mRNA in the mammary tissue in response to different milking intervals may be associated with changes in mammary tight junctions caused by reduced milking frequency (Stelwagen et al., 1994).

In conclusion, the results obtained from experiments involving bST-infused lactating cows and mammary explant cultures provide evidence that additional bST augments $\beta$-casein mRNA levels in lactating mammary tissue. Moreover, in lactating animals, the amount of $\beta$-casein mRNA is influenced by milking intervals, and loss of the mRNA resulting from extended non-milking intervals may be recovered by bST treatment.

\section{ACKNOWLEDGMENTS}

Acknowledgment is made to $\mathrm{H}$. A. Tucker from Michigan State University for providing bovine mammary tissue from bST infusion experiments. The authors also thank Steven P. Washburn for his critical comments and revision of the manuscript.

\section{REFERENCES}

Accorsi, P. A., B. Pacioni, C. Pezzi, M. Forni, D. J. Flint, and E. Seren. 2002. Role of prolactin, growth hormone and insulin-like growth factor 1 in mammary gland involution in the dairy cow. J. Dairy Sci. 85:507-513.

Argetsinger, L. S., G. S. Campbell, X. Yang, B. A. Witthuhn, O. Silvennoinen, J. N. Ihle, and C. Carter-Su. 1993. Identification 
of JAK2 as a growth hormone receptor-associated tyrosine kinase. Cell 74:237-244.

Bauman, D. E. 1999. Bovine somatotropin and lactation: From basic science to commercial application. Domest. Anim. Endocrinol. 17:101-116.

Bauman, D. E., and R. G. Vernon. 1993. Effects of exogenous bovine somatotropin on lactation. Annu. Rev. Nutr. 13:437-461.

Binelli, M., W. K. Vanderkooi, L. T. Chapin, M. J. Vandehaar, J. D. Turner, W. M. Moseley, and H. A.Tucker. 1995. Comparison of growth hormone-releasing factor and somatotropin: Body growth and lactation of primiparous cows. J. Dairy Sci. 78: 2129-2139.

Campbell, G. S., L. S. Argetsinger, J. N. Ihle, P. A. Kelly, J. A. Rillema, and C. Carter-Su. 1994. Activation of JAK2 tyrosine kinase by prolactin receptors in $\mathrm{Nb} 2$ cells and mouse mammary gland explants. Proc. Natl. Acad. Sci. 91:5232-5236.

Capuco, A. V., D. L. Wood, R. Baldwin, K. Mcleod, and M. J. Paape. 2001. Mammary cell number, proliferation, and apoptosis during a bovine lactation: Relation to milk production and effect of bST. J. Dairy Sci. 84:2177-2187.

Choi, Y. J., W. L. Keller, I. E. Berg, C. S. Park, and A. G. Mackinlay. 1988. Casein gene expression in bovine mammary gland. J. Dairy Sci. 71:2898-2903.

Chomczynski, P., P. Qasba, and Y. J. Topper. 1984. Essential role of insulin in transcription of the rat 25,000 molecular weight casein gene. Science 226:1326-1328.

Cowie, A. T., G. S. Knaggs, and J. S. Tindal. 1964. Complete restoration of lactation in the goat after hypophysectomy. J. Endocrinol. 28:267-279.

Dahl, G. E., L. T. Chapin, W. M. Moseley, and H. A. Tucker. 1993. Galactopoietic effects of recombinant somatotropin and growth hormone-releasing factor in dairy cows. J. Dairy Sci. 76:15501557.

Devinoy, E., L. M. Houdebine, and C. Delouis. 1978. Role of prolactin and glucocorticoids in the expression of casein genes in rabbit mammary gland organ culture. Quantification of casein mRNA. Biochim. Biophys. Acta 517:360-366.

German, T., and I. Barash. 2002. Characterization of an epithelial cell line from bovine mammary gland. In Vitro Cell Dev. Biol. Anim. 38:282-292.

Gertler, A., N. Cohen, and A. Maoz. 1983. Human growth hormone but not ovine or bovine growth hormones exhibits galactopoietic prolactin-like activity in organ culture from bovine lactating mammary gland. Mol. Cell. Endocrinol. 33:169-182.

Glimm, D. R., V. E. Baracos, and J. J. Kennelly. 1990. Molecular evidence for the presence of growth hormone receptors in the bovine mammary gland. J. Endocrinol. 126: R5-R7.

Grimm, S. L., T. N. Seagroves, E. B. Kabotyanski, R. C. Hovey, B. K. Vonderhaar, J. P. Lydon, K. Miyoshi, L. Hennighausen, C. J. Ormandy, A. V. Lee, M. A. Stull, T. L. Wood, and J. M. Rosen. 2002. Disruption of steroid and prolactin receptor patterning in the mammary gland correlates with a block in lobuloalveolar development. Mol. Endocrinol. 16: 2675-2691.

Knight, C. H., P. A. Fowler, and C. J. Wilde. 1990. Galactopoietic and mammogenic effects of long-term treatment with bovine growth hormone and thrice daily milking in goats. J. Endocrinol. 127:129-138.

Knight, C. H., J. E. Hillerton, M. A. Kerr, R. M. Teverson, A. Turvey, and C. J. Wilde. 1992a. Separate and additive stimulation of bovine milk yield by the local and systemic galactopoietic stimuli of frequent milking and growth hormone. J. Dairy Res. 59:243-252

Knight, C. H., J. E. Hillerton, R. M. Teverson, and A. Winter. 1992b. Biopsy of the bovine mammary gland. Br. Vet. J. 148:129-132.

Li, P., P. S. Rudland, D. G. Fernig, L. M. Finch, and C. J. Wilde. 1999. Modulation of mammary development and programmed cell death by the frequency of milk removal in lactating goats. J. Physiol. 519(Pt 3):885-900.

Matusik, R. J., and J. M. Rosen. 1980. Prolactin regulation of casein gene expression: Possible mediators. Endocrinology 106:252-259.

McFadden, T. B., R. M. Akers, and W. E. Beal. 1989. Influence of breed and hormones on production of milk proteins by mammary explants from prepubertal heifers. J. Dairy Sci. 72:1754-1763.

Plath-Gabler, A., C. Gabler, F. Sinowatz, B. Berisha, and D. Schams. 2001. The expression of the IGF family and GH receptor in the bovine mammary gland. J. Endocrinol. 168:39-48.

Plaut, K., D. E. Bauman, N. Agergaard, and R. M. Akers. 1987. Effect of exogenous prolactin administration on lactational performance of dairy cows. Domest. Anim. Endocrinol. 4:279-490.

Politis, I., E. Lachance, E. Block, and J. D. Turner. 1989. Plasmin and plasminogen in bovine milk: A relationship with involution? J. Dairy Sci. 72: 900-906.

Rosen, J. M., R. J. Matusik, D. A. Richards, P. Gupta, and J. R. Rodges. 1980. Multihormonal regulation of casein gene expression at the transcription and post-transcriptional level in the mammary gland. Recent Progress Hormone Res. 36:156-192.

SAS User's Guide: Statistics, Version 6. 1990. 4th ed. SAS Inst., Inc., Cary, NC.

Sinowatz, F., D. Schams, S. Kolle, A. Plath, D. Lincoln, and M. J. Waters. 2000. Cellular localization of GH receptor in the bovine mammary gland during mammogenesis, lactation and involution. J. Endocrinol. 166:503-510.

Stelwagen, K., S. R. Davis, V. C. Farr, S. J. Eichler, and I. Politis. 1994. Effect of once daily milking and concurrent somatotropin on mammary tight junction permeability and yield of cows. J. Dairy Sci. 77:2994-3001.

Topper, Y. J., and C. S. Freeman. 1980. Multiple hormone interactions in the developmental biology of the mammary gland. Physiol. Rev. 60:1049-1106.

Topper, Y. J., T. Oka, and B. K. Vonderhaar, 1975. Techniques for studying development of normal mammary epithelial cells in organ culture. Methods Enzymol. 39:443-454.

Wakao, H., F. Gouilleux, and B. Groner. 1994. Mammary gland factor (State 5) is a novel member of the cytokine regulated transcription factor gene family and confers the prolactin response. EMBO J. 13:2182-2191.

Wheeler, T. T., M. K. Broadhurst, H. B. Sadowski, V. C. Farr, and C. G. Prosser. 2001. Stat5 phosphorylation status and DNA-binding activity in the bovine and murine mammary glands. Mol. Cell. Endocrinol. 176:39-48.

Wilde C. J., C. V. Addey, P. Li, and D. G. Fernig. 1997. Programmed cell death in bovine mammary tissue during lactation and involution. Exp. Physiol. 82:943-953.

Yang, J, J. J. Kennelly, and V. E. Baracos. 2000a. The activity of transcription factor Stat5 responds to prolactin, growth hormone, and IGF-I in rat and bovine mammary explant culture. J. Anim. Sci. 78:3114-3125.

Yang, J., J. J. Kennelly, and V. E. Baracos. 2000b. Physiological levels of Stat5 DNA binding activity and protein in bovine mammary gland. J. Anim. Sci. 78:3126-3134. 